\title{
RECONNAISSANCE REPORT ON THE 2000 TOTTORI-KEN SEIBU EARTHQUAKE
}

\author{
Junji KIYONO ${ }^{1}$, Tadafumi FUJIWARA ${ }^{2}$, Masanori HAMADA ${ }^{3}$, Takao HASHIMOTO ${ }^{4}$, \\ $\mathrm{Koji} \mathrm{ICHII}^{5}$, Ryoji ISOYAMA ${ }^{6}$, Kazuo KONAGAI ${ }^{7}$, Masakatsu MIYAJIMA ${ }^{8}$, \\ Hitomi MURAKAMI ${ }^{9}$, Susumu NAKAMURA ${ }^{10}$, Tomofumi NOZAKI ${ }^{11}$, \\ and Yoichi TAJI ${ }^{12}$ \\ ${ }^{1}$ Member of JSCE, Assoc. Professor, Graduate School of Engineering, Kyoto University \\ (Kyotodaigaku Katsura, Nishikyo-ku, Kyoto 615-8540, Japan) \\ E-mail: kiyono@quake.kuciv.kyoto-u.ac.jp \\ ${ }^{2}$ Member of JSCE, Technology Center, Taisei Corporation \\ (344-1 Nasechou, Tozuka-ku, Yokohama 245-0051, Japan) \\ ${ }^{3}$ Fellow of JSCE, Professor, Faculty of Science and Engineering, Waseda University \\ (3-4-1 Ohkubo, Shinzyuku-ku, Tokyo 169-8555, Japan) \\ ${ }^{4}$ Member of JSCE, Chiyoda Engineering Consultants Co., Ltd. \\ (3-3-7 Iidabashi, Chiyoda-ku, Tokyo 102-0072, Japan) \\ ${ }^{5}$ Member of JSCE, Assoc. Professor, Graduate School of Engineering, Hiroshima University \\ (1-4-1 Kagamiyama, Higashi-Hiroshima, 739-8527, Japan) \\ ${ }^{6}$ Member of JSCE, Japan Engineering Consultants Co., Ltd. \\ (5-33-11Honcho, Nakano-ku, Tokyo 164-8601, Japan) \\ ${ }^{7}$ Member of JSCE, Professor, Institute of Industrial Science, University of Tokyo \\ (4-6-1 Komaba, Meguro-ku, Tokyo 153-8505, Japan) \\ ${ }^{8}$ Member of JSCE, Professor, Graduate School of Natural Science and Technology, Kanazawa University \\ (Kakuma, Kanazawa, Ishikawa 920-1192, Japan) \\ ${ }^{9}$ Member of JSCE, Assoc. Professor, Graduate School of Science and Engineering, Yamaguchi University \\ (2-16-1 Tokiwadai, Ube, Yamaguchi 755-8611, Japan) \\ ${ }^{10}$ Member of JSCE, Professor, College of Engineering, Nihon University \\ (Tamuracho, Koriyama, Fukushima 963-8642, Japan) \\ ${ }^{11}$ Member of JSCE, Road Bureau, Ministry of Land, Infrastructure and Transport \\ (2-1-3 Kasumigaseki, Chiyoda-ku, Tokyo 100-8918, Japan) \\ ${ }^{12}$ Member of JSCE, Institute of Technology, Shimizu Corporation \\ (3-4-7 Koshinakajima, Kohto-ku, Tokyo 135-8530, Japan)
}

Damage done to civil structures by the 2000 Tottori-ken Seibu Earthquake was investigated. Field surveys were made from October $8-10$ by eight members dispatched by the JSCE in cooperation with other researchers. Descriptions are given of the earthquake, seismic ground motion; the damage done to such civil structures as roads, road bridges, lifelines, dams, port facilities; slope failures; and public risk management. Although peak ground accelerations were extremely intensive, structural damage was not as severe as compared with the average damage caused by past earthquakes in Japan. Such disaster responses as search and rescue activities, emergency responses, disaster information communication, and victim supports are discussed.

Key Words: the 2000 Tottori-ken Seibu Earthquake, reconnaissance report, seismic ground motion, damage to civil structures, risk management, disaster response

\section{INTRODUCTION}

An earthquake of $M_{J} 7.3$ occurred at 13:30 on October 6, 2000 in western Tottori. Seismic intensi- ties of 6+ in the Japan Meteorological Agency (JMA) scale were recorded at Sakaiminato and Hino. There were 182 casualties (no dead), 433 fully collapsed and 3,084 partially collapsed houses ${ }^{2}$.

(Copy of Dobokugakkai Ronbunsyuu A Vol.63 No.2, 374-385, 2007.6) 
The Council of the Japan Society of Civil Engineers (JSCE) dispatched a reconnaissance team in cooperation with the affiliated Earthquake Engineering Committee (Chair as of 2000: Tsuneo Katayama, President of the National Research Institute for Earth Science and Disaster Prevention). The investigation was made from October 8 to 10,2000 by eight persons (by some members from October 20 to 22) (see Appendix).

\section{EARTHQUAKE GROUND MOTION}

Prompt announcement ${ }^{1)}$ by the Japan Meteorological Agency located the hypocenter at lat. $35.3^{\circ} \mathrm{N}$, long. $133.4^{\circ} \mathrm{E}$, and a depth of $10 \mathrm{~km}$ (Fig.1). The Japan Meteorological Agency Magnitude $\left(M_{J}\right)$ was 7.3, and the Moment Magnitude $\left(M_{W}\right) 6.6^{3), 4)}$. Distributions of the seismic intensities and aftershocks ${ }^{5)}$ indicated the existence of a $20-30 \mathrm{~km}$ long, $10-15 \mathrm{~km}$ wide, left-lateral strike-slip fault oriented northwestsoutheast ${ }^{336)}$. In the vicinity of the hypocenter, more than 20-30 earthquakes larger than $M_{J} 1.0$ occurred per hour just after the main shock, the number gradually decreasing with time ${ }^{7)}$. The largest aftershock in the focal region, $M_{J} 5.5$, occurred at 20:51 on Oct. 8, a Japanese seismic intensity of 5- being recorded at Saihaku. Other earthquake shock groups were induced to the southwest of the hypocenter area (Fig.1). An earthquake that killed more than 1000 people took place in 1943 in eastern Tottori. In the same eastern focal area as this 2000 earthquake, earthquake swarms, including an $M_{J} 5.0$ earthquake, occurred in 1989 and 1990 near Mt. Kamakura in the northwest part of Hino, and $M_{J} 3.0-5.0$ earthquakes occurred in 1996, 1997, and July 2000 in Yonago.

The Japan Meteorological Agency, the National Research Institute for Disaster Prevention (K-net and KiK-net), and the Fire Defense Agency had placed many seismographs around the source area, and they provided much useful information about seismic ground motion when the 2000 earthquake struck. Joint dense observations of the aftershocks ${ }^{5)}$ were made by several universities just after the main event.

The seismic intensity of $6+$ (instrumental seismic intensity 6.0) at Sakaiminato City was calculated from seismograms recorded at the Sakai Meteorological Observatory. The peak ground acceleration was $763 \mathrm{gal}(\mathrm{EW})$. The seismogram recorded at the Sakaiminato City Hall, about $1 \mathrm{~km}$ from the observatory, showed ground accelerations of $213 \mathrm{gal}(\mathrm{EW})$, 113gal (NS), and 93gal (UD) (seismic intensity: 6-, instrumental seismic intensity: 5.6).

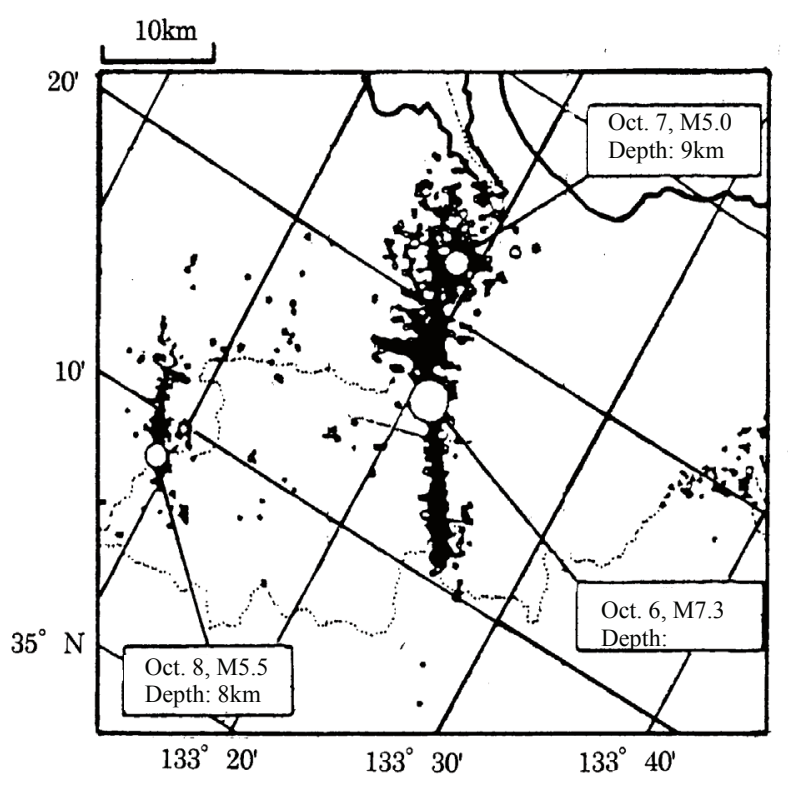

Fig.1 Epicenter and aftershock activities in western Tottori.

Table 1 Peak accelerations and instrumental seismic intensities recorded at city offices and several K-Net and KiK-Net records.

\begin{tabular}{|c|c|c|c|c|c|}
\hline \multirow[t]{2}{*}{$\begin{array}{c}\text { Local } \\
\text { Authority }\end{array}$} & \multicolumn{3}{|c|}{$\begin{array}{c}\text { Peak Accelerations } \\
\text { (gal) } \\
\text { Predominant Period } \\
\text { (sec) }\end{array}$} & \multirow[t]{2}{*}{$\begin{array}{l}\text { Instru- } \\
\text { mental } \\
\text { Seismic } \\
\text { Intensity }\end{array}$} & \multirow[t]{2}{*}{$\begin{array}{l}\text { Scale of } \\
\text { Intensity }\end{array}$} \\
\hline & EW & NS & UD & & \\
\hline \multirow{2}{*}{ Sakaiminato } & 213 & 113 & 93 & \multirow{2}{*}{5.6} & \multirow{2}{*}{$6-$} \\
\hline & 1.71 & 1.71 & 0.73 & & \\
\hline \multirow{2}{*}{ Yonago } & 383 & 314 & 307 & \multirow{2}{*}{5.8} & \multirow{2}{*}{$6-$} \\
\hline & 1.14 & 0.41 & 0.12 & & \\
\hline \multirow{2}{*}{ Hino } & 1482 & 675 & 1407 & \multirow{2}{*}{6.3} & \multirow{2}{*}{$6+$} \\
\hline & 0.45 & 0.44 & 0.10 & & \\
\hline \multirow{2}{*}{ Saihaku } & 802 & 607 & 1077 & \multirow{2}{*}{5.9} & \multirow{2}{*}{$6-$} \\
\hline & 0.49 & 0.31 & 0.07 & & \\
\hline \multirow{2}{*}{ Aimi } & 952 & 865 & 756 & \multirow{2}{*}{5.9} & \multirow{2}{*}{$6-$} \\
\hline & 0.42 & 0.14 & 0.06 & & \\
\hline \multirow{2}{*}{ Mizoguchi } & 816 & 522 & 433 & \multirow{2}{*}{5.7} & \multirow{2}{*}{$6-$} \\
\hline & 0.35 & 0.37 & 0.08 & & \\
\hline \multirow{2}{*}{ Kishimoto } & 593 & 445 & 541 & \multirow{2}{*}{5.6} & \multirow{2}{*}{$6-$} \\
\hline & 0.24 & 0.73 & 0.04 & & \\
\hline \multirow{2}{*}{ Yodoe } & 342 & 333 & 148 & \multirow{2}{*}{5.6} & \multirow{2}{*}{$6-$} \\
\hline & 0.85 & 0.76 & 0.68 & & \\
\hline \multirow{2}{*}{ Hiezu } & 326 & 258 & 145 & \multirow{2}{*}{5.5} & \multirow{2}{*}{$6-$} \\
\hline & 0.79 & 0.76 & 0.35 & & \\
\hline Sakaiminato & 763 & 299 & 184 & \multicolumn{2}{|c|}{$\begin{array}{c}\text { Sakai Meteorological } \\
\text { Observatory }\end{array}$} \\
\hline Sakaiminato & 302 & 209 & 93 & \multicolumn{2}{|c|}{$\begin{array}{l}\text { Port and Harbour Re- } \\
\text { search Institute }^{10)}\end{array}$} \\
\hline Hino & 753 & 927 & 776 & TT & $02^{9)}$ \\
\hline Hakata & 606 & 719 & 631 & SMI & $01^{11)}$ \\
\hline Kohu & 573 & 726 & 404 & TT1 & $07^{11)}$ \\
\hline Nichinan & 596 & 628 & 289 & TTI & $09^{11)}$ \\
\hline
\end{tabular}




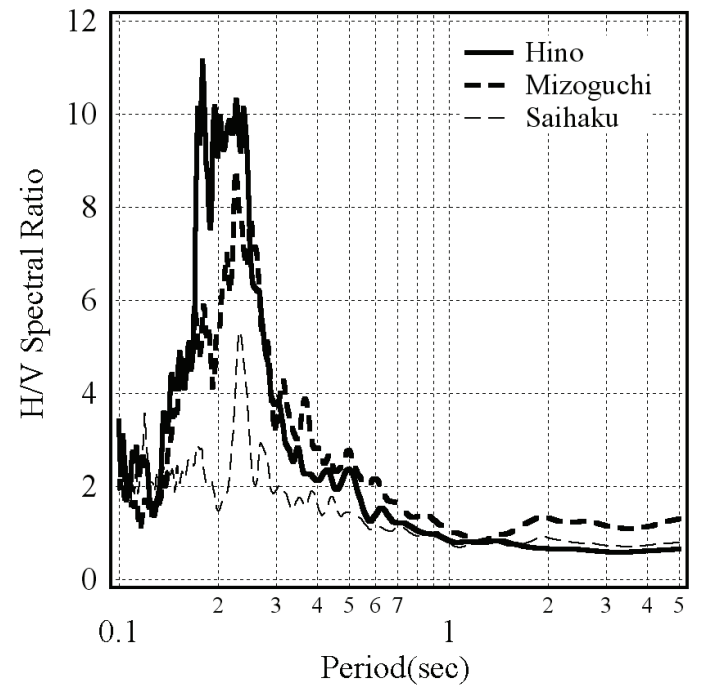

Fig. $2 \mathrm{H} / \mathrm{V}$ spectra of sites near the epicenter.

Other seismograms recorded at Sakaiminato by the Ministry of Transport ${ }^{9}$ ) showed much smaller accelerations than those at the city hall; 302gal (EW), 209gal (NS), and 93gal (UD). Table 1 gives the peak ground accelerations, instrumental seismic intensities, and seismic intensity scales as recorded by the principal local governments near the fault.

The seismic intensity of 6+ (instrumental seismic intensity 6.0) at Sakaiminato City was calculated from seismograms recorded at the Sakai Meteorological Observatory. The peak ground acceleration was $763 \mathrm{gal}(\mathrm{EW})$. The seismogram recorded at the Sakaiminato City Hall, about $1 \mathrm{~km}$ from the observatory, showed ground accelerations of $213 \mathrm{gal}$ (EW), 113gal (NS), and 93gal (UD) (seismic intensity: 6-, instrumental seismic intensity: 5.6). Other seismograms recorded at Sakaiminato by the Ministry of Transport ${ }^{9)}$ showed much smaller accelerations than those at the city hall; 302gal (EW), 209gal (NS), and 93gal (UD). Table 1 gives the peak ground accelerations, instrumental seismic intensities, and seismic intensity scales as recorded by the principal local governments near the fault.

Seismograms were not recorded by the local governments of Hino, Saihaku, and Mizoguchi (upper part of Table 1), but large peak acceleration amplitudes exceeding $1 \mathrm{G}$ were recorded. Accelerations, for which observation points were close, differ markedly in the records at Sakaiminato (the meteorological observatory, city hall, and harbor office) and at Hino (the KiK-net site and town hall). The seismic intensities accurately indicate the magnitudes of ground motion at the observation points but do not provide an outline of the damage done to various structures in the area because they represent pinpoint information only.

To determine the characteristics of seismic

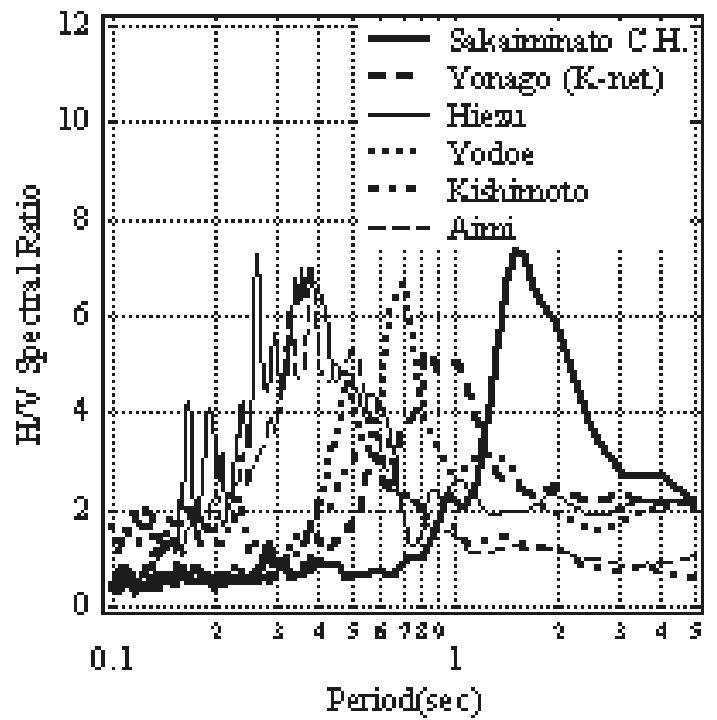

Fig. $3 \mathrm{H} / \mathrm{V}$ spectra of sites on relatively soft ground.

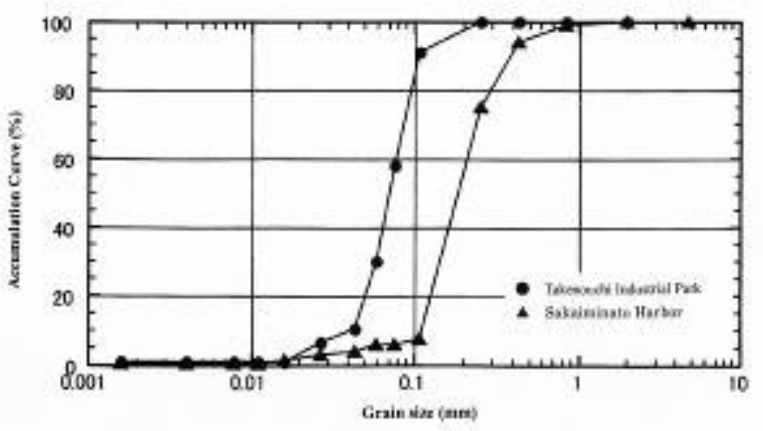

Fig. 4 Grain size accumulation curve at the Takenouchi industrial park and Sakaiminato fishery wharf.

ground motion at the earthquake observation sites in each local government area, H/V spectra were calculated from the microtremors. The $\mathrm{H} / \mathrm{V}$ spectra at the Hino, Mizoguchi, and Saihaku town halls (instruments had been installed on relatively hard ground near the epicenter) are shown in Fig.2. Predominant periods are about $0.2 \mathrm{sec}$ at these locations. $\mathrm{H} / \mathrm{V}$ spectra at the Aimi, Kishimoto, Yodoe, and Hiezu Town Halls, and the Yonago (K-net), and Sakaiminato City Halls are shown in Fig.3. The predominant periods are about $0.3-0.4 \mathrm{sec}$ at Aimi and Hiezu, and $0.7-1.5 \mathrm{sec}$ at Kishimoto, Yodoe, Yonago (K-net), and Sakaiminato.

\section{GEOLOGICAL AND GROUND CONDITIONS}

Sakaiminato, Yonago, and Yasuki cities are underlain by an alluvial sand layer. The ground under western Yonago and eastern Yasuki is composed partly of eruptive rocks of the Tertiary period ${ }^{11), 12)}$. 


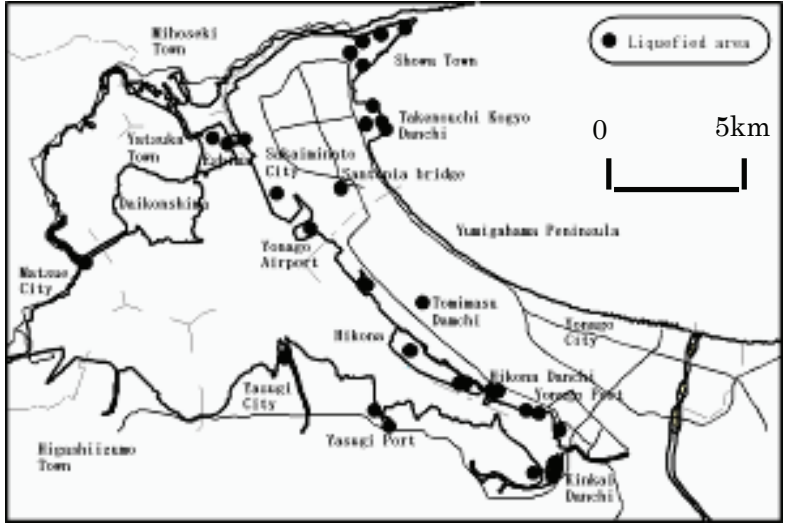

Fig. 5 Confirmed liquefaction sites.

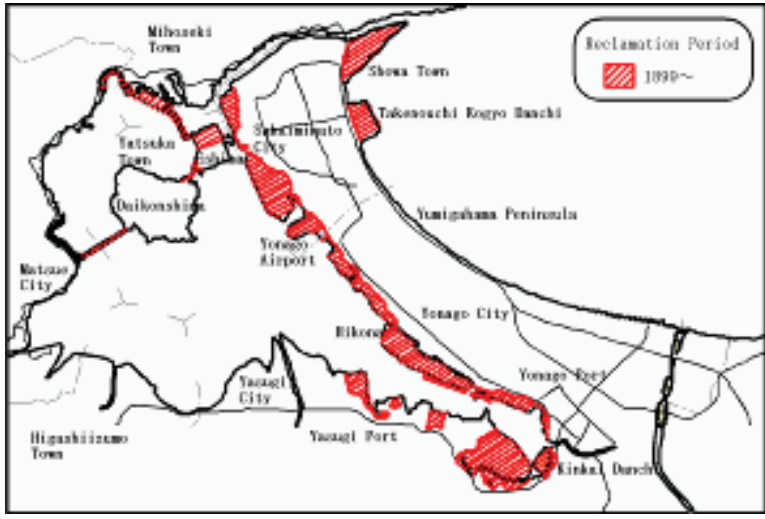

Fig. 6 Reclaimed ground on the Nakaumi littoral.

This investigation indicated that the sand boiled out by liquefaction at the Takenouchi Industrial Park in Sakaiminato consisted of a large amount of black, fine-grain sand. Fig.4 shows grain-size accumulation curves for boiled-out sand at the Industrial Park and the Sakaiminato fishery wharf where quay walls were damaged. The boiled-out sand at the Takenouchi Industrial Park contains more fine grains than that at the fishery wharf.

In the vicinity of the epicenter, the mountainous area on the upper Hino River is composed mainly of Mesozoic granite, and part of Hino Town is underlain by argillaceous schist and metamorphic rocks. Even the newer rocks had markedly developed joints, and flaked fallen rocks were found in various locations.

\section{LIQUEFACTION}

Liquefaction occurred during the 2000 Tottori-ken Seibu Earthquake at the Nakaumi littoral in Sakaiminato, Yonago, Yasuki, and Matsue cities, all within $30 \mathrm{~km}$ of the epicenter.

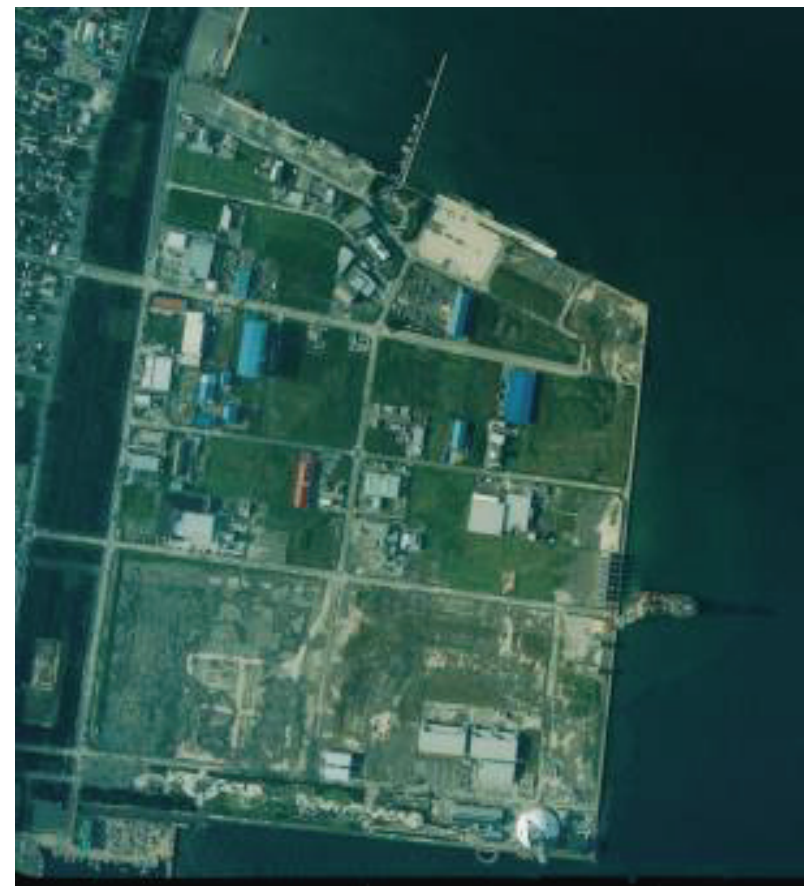

Photo 1 Aerial photograph of the Takenouchi Industrial Park In Sakaiminato taken after the earthquake (October 7, 2000).

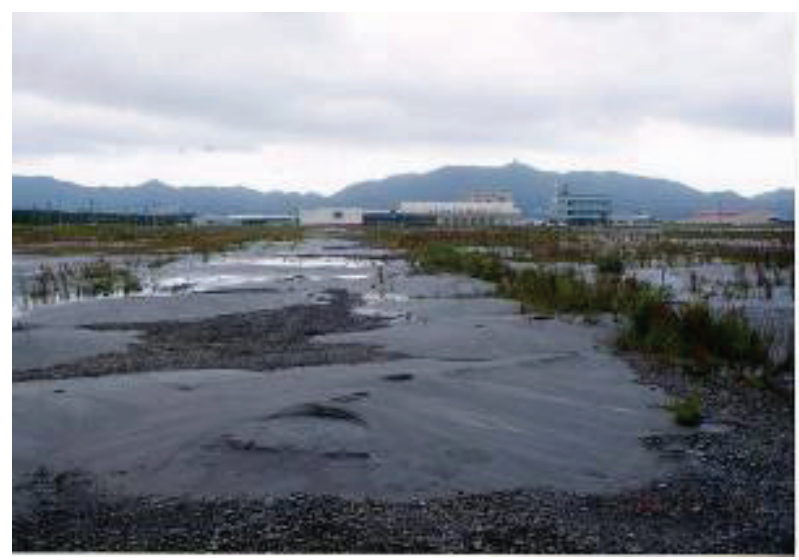

Photo 2 Boiled-out sand produced by liquefaction (Takenouchi Industrial Park).

Fig.5 shows locations where boiled-out sand and cracks in the ground were found during our reconnaissance. The Yumigahama Peninsula, running from Sakaiminato to Yonago, is an $18 \mathrm{~km}$-long, $4 \mathrm{~km}$-wide sandbar ${ }^{12)}$ composed of soil deposited by the Hino River. It has been reclaimed for farm and industrial land $\left(\right.$ Fig. $\left.\mathbf{6}^{13)}\right)$. The figure shows that the area on the Miho Harbor side is mostly natural coast line, whereas on the Nakaumi side most is reclaimed ground. 


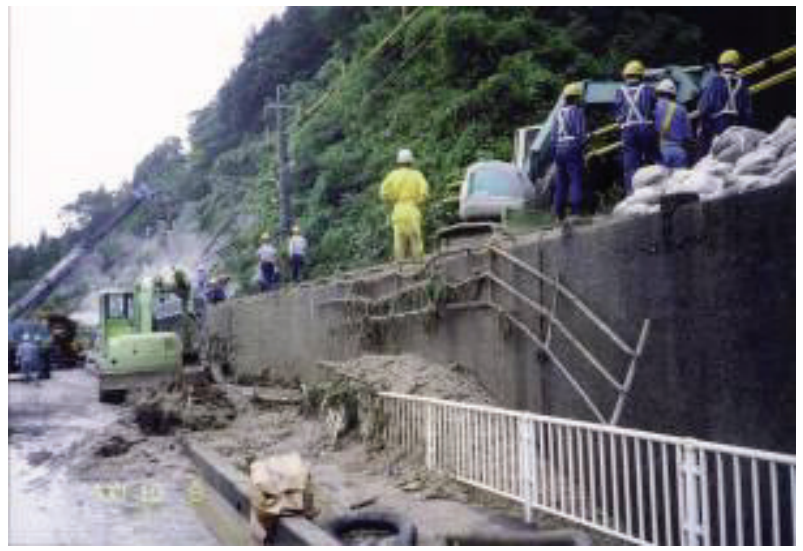

Photo 3 Slope failure along the JR Hakubi line and Route 181 in Kaibara, Hino.

Figs.5 and 6 show that liquefaction was concentrated in the Takenouchi industrial park (Photo 1), Showa Town, and reclaimed ground near Yonago Harbor. In the industrial park and Showa Town, liquefaction was extensive (Photo 2). Damage included land subsidence around structures, heaving of piers, subsidence of and cracks in aprons, unequal subsidence and deformation of lightweight structures due to lateral flowage, and destruction of water supply pipelines. In Hatagasaki (Yonago Harbor), the Hikona and Nishikiumi housing estates, and Minatoyama Park, there was damage both to the ground and structures.

Dislocation of the airstrip at Yonago Airport and damage to market gardens in the Hikona reclaimed ground area occurred due to strong ground motion and liquefaction. At Yonago Airport, a runaway in the center that had been extended by $500 \mathrm{~m}$ in 1996 sustained damage; two $1 \mathrm{~cm}$ wide cracks in the transverse direction and a 1-2m step appeared. In the Hikona area, market gardens were damaged by the boiling sand produced by liquefaction. Economic loss amounted to approximately 80 million yen.

According to Japanese records ${ }^{14)}$, liquefaction occurred in Yonago during the 1943 Tottori earthquake, in the 1946 Nankai earthquake, and in the 1925 Miho Harbor earthquake. The 2000 Tottori-ken Seibu Earthquake produced more liquefaction than in those past earthquakes, a reminder of the enormous damage that can be caused by liquefaction.

\section{SLOPE AND SOIL FAILURE}

\section{(1) Outline}

After the main shock on October 6, 2000, it took some time to check the damage done in mountain

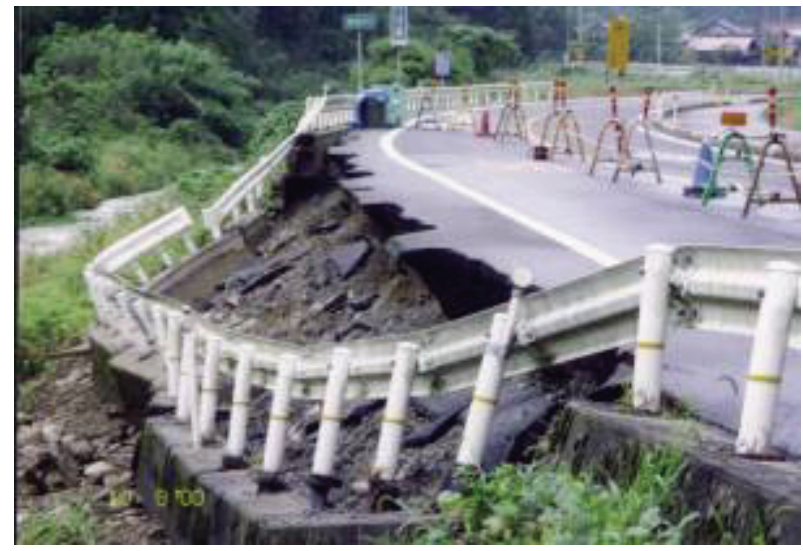

Photo 4 Damaged guard rail caused by slope failure in Nigotani, Hino.

areas. All the slope failures finally had been identified by October 8. Landslips as of 12:00 on October 10 totalled 117, including 30 in Hino (4 road closures) and 22 in Mizoguchi. Totally, 348 instances of slope damage of various types were confirmed ${ }^{2}$. Compared to the 2000 Kohzushima Kinkai Earthquake, large slope failures were few, but peak ground motion was larger. The soil in the western Daisen area is a consolidated ash flow produced by the eruption of Mt. Daisen about 26,000 years ago, and its adherence properties prevented slope failure.

\section{(2) Hino Town}

In Hino, roads were closed in 17 places, including Route 180 in Shimokurosaka, due to slope failures. As for West Japan Railway (JR West), the tracks of its Hakubi line parallel to Route 180 were cut due to slope failure (Photo 3), and the JR San' in Line and most local lines in the Kinki and Chugoku Districts had to cancel operations. In a $500 \mathrm{~m}$ range that included the Nezuma Tunnel (175m), four landslides occurred. On Route 180, a stretch between Kurosaka and Neu was closed to traffic because of rock falls and landslides, and a farm road (the Nigotani-Takiyama one) and the Kamiishimi-Kurosaka road had to be used as detours.

Temporary guard fences had been set up by 17:00 on October 14, and Route 180 re-opened on one side. There was one-side traffic along the Mashumi River in Nigotani District (Photo 4) because of an $80 \mathrm{~m}$ long, $2 \mathrm{~m}$ wide slope failure on the river side.

\section{(3) Saihaku Town}

The baseball field of the Hosshoji Junior High School, located on a hill, suffered a 2-3m crack due to a landslide of its earthfill (Photo 5). 


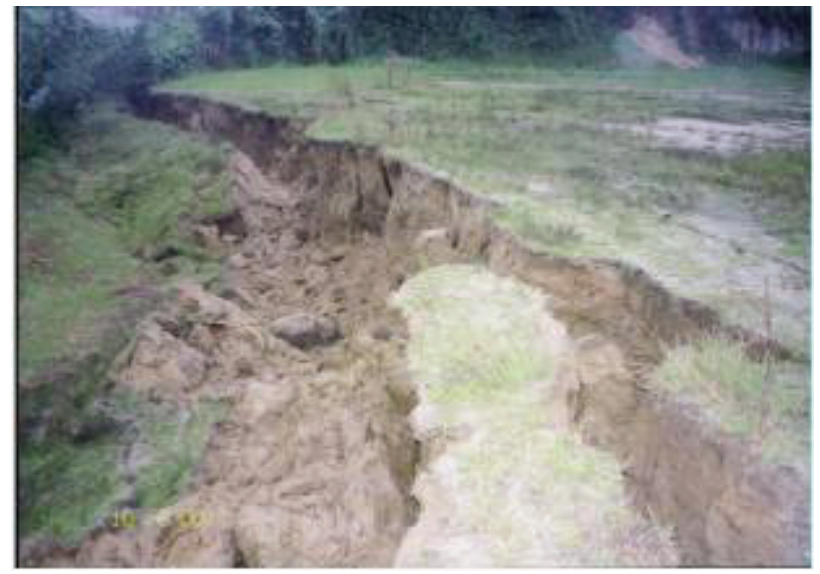

Photo 5 Tension crack in the baseball field at Hosshoji Junior High School, Saihaku.

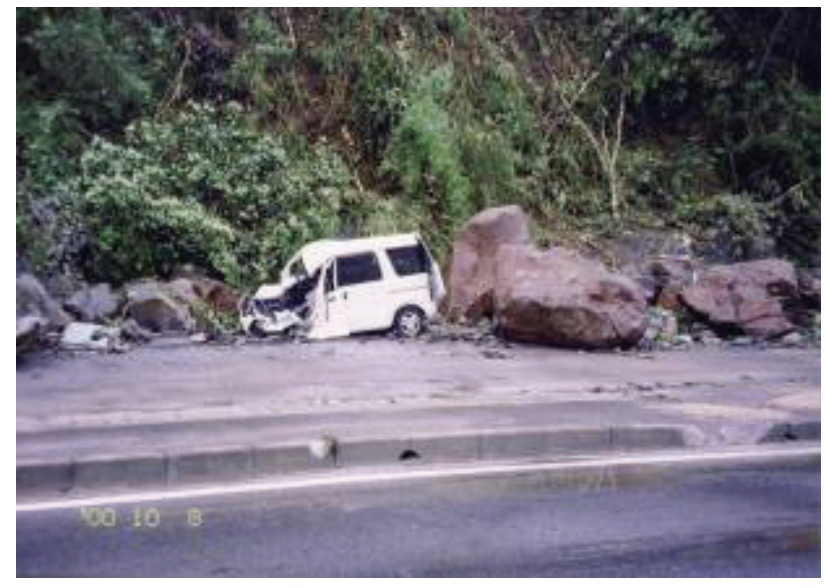

Photo 6 Car damaged by fallen rocks near the prefectural road in Udai, Mizoguchi.

Table 2 Number of roads controlled because of the 2000 Tottori-ken Seibu Earthquake.

\begin{tabular}{|c|c|c|c|c|c|}
\hline & Tottori & Shimane & Okayama & Hiroshima & Remarks \\
\hline $\begin{array}{c}\text { National Ex- } \\
\text { pressway }\end{array}$ & 1 & 1 & $(1)$ & $\begin{array}{c}\text { Yonago Road } \\
\text { (Yonago-Kuze) }\end{array}$ \\
\hline $\begin{array}{c}\text { Ordinary Toll } \\
\text { Road }\end{array}$ & & 1 & 1 & & Yasuki Road \\
\hline $\begin{array}{c}\text { Ordinary Na- } \\
\text { tional Road }\end{array}$ & 1 & 2 & 4 & 2 & \\
\hline $\begin{array}{c}\text { Auxiliary Na- } \\
\text { tional Road }\end{array}$ & 9 & $\begin{array}{l}\text { Prefectural } \\
\text { Road }\end{array}$ & 9 & 1 & \\
\hline \\
*Total number at 20:00 on October 7 \\
* Based on the report of the road administrator \\
\hline
\end{tabular}

\section{(4) Mizoguchi Town}

A landslide occurred in the vicinity of the prefectural road near an amusement park called Onikko Land in the Udai District of Mizoguchi. A parked car was destroyed by falling rocks and soil, and the driver slightly injured (Photo 6).

\section{(5) Daisen Area}

A landslide occurred on Mt. Sankohou in Daisen National Park, and 5 climbers had to be rescued. The stone triangulation marker at the $1,711 \mathrm{~m}$ elevation of the Yayama summit of Daisen slid with its foundation $3 \mathrm{~m}$ to the north, and its altitude decreased by about $2 \mathrm{~m}$.

\section{(6) Remarks}

Forests cover $89.7 \%$ of Hino. Recently, the forestry industry is in difficulty because of decreased timber prices, the aging of those engaged in forestry businesses, lack of new employment, and increased labor costs. Moreover, many standing trees have decayed due to the increase in pine weevils. This destruction may be one reason for the slope failures that occurred. Maintenance of forests is a major factor in avoiding slope failures caused by earthquakes and other natural disasters.

\section{ROADS AND BRIDGES}

Public officers in charge of roads in 14 prefectures conducted emergency checks after the 2000 Tottori-ken Seibu Earthquake. Table 2 presents an overview of the damage done to roads in Tottori.

There was little damage to bridges. Only one small one, the Harada Bridge (a skew bridge, span $7 \mathrm{~m}$ ) on the town road (Akatani Road), collapsed. 


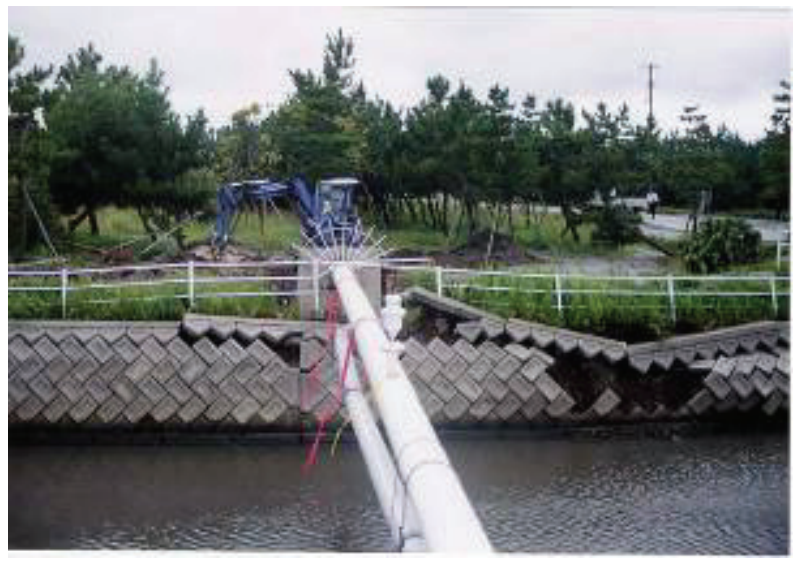

Photo 7 Damage to an aqueduct over a catch drain in the western part of the Takenouchi Industrial Park.

Most of the damage incurred was caused by the offset between the bridge's span and the abutment. A landslide in the mountain area was caused by strong ground motion. The Yonago Highway was damaged at one place, and slope failures and rock falls occurred on Routes 180, 181, and other prefectural roads. Traffic on these roads had to be controlled after the earthquake, but could be discontinued after a short period. No national roads were restricted after October 17.

\section{LIFELINES}

Water supplies were cut at Saihaku, Aimi, and Hino in western Tottori, affecting some 2,800 households. On October 11, 6 days after the earthquake, 1,200 households still suffered cut offs or murky water, but local governments and the Self Defense Forces supplied potable water by tank trucks. In Tottori, 5,744 households were affected by water cut offs, and counting those in neighboring prefectures ${ }^{2)}$, the total was 6,801 households.

On October 9, 3 days after the earthquake, temporary baths were opened to the public in three camps in Hino by the Self Defense Forces. In addition, hotels and ryokans in Yonago, Saihaku, and Yodoe provided baths at no charge to lesson the inconvenience to inhabitants.

The Yonago Water Bureau reported damage to the water supply system. It supplies water to 2 cities and 1 village; Yonago and Sakaiminato and Hiezu, 178,000 people being served about $70,000 \mathrm{~m}^{3}$ of water per day. The respective total lengths of the transmission, distribution, and supply pipes were 7.5, 21 , and $1123 \mathrm{~km}$. According to the water department, damage to distribution pipes tended to occur where there was liquefaction. Water and industrial pipelines at the Takenouchi industrial park in Sakaiminato, in particular, sustained severe damage due to liquefaction. Photo 7 shows a damaged aqueduct bridge at the southwest entrance to the park. Deformation occurred because the bank protection, a catch drain, moved due to liquefaction and the width of the drain was reduced. The ground subsided as well. As for damage to pipelines, small caliber pipes of less than $50 \mathrm{~mm}$ showed the most damage. Also, a few large caliber ones of more than $300 \mathrm{~mm}$ were damaged. The most severely damaged pipes were those of cast iron, most failure modes being due to repeated separation and penetration behavior. Damage to steel pipes was second, most caused by the cutting of screw parts. Few asbestos cement pipes were damaged despite their low strength. This is because they had not been buried under recently developed ground that was considered liquefiable. They became damaged due to buckling and separation at joints.

After the 1995 Hyogo-ken Nanbu Earthquake, a mutual aid system was formed by the local governments of Yonago in Tottori; Hofu, Iwakuni, Ube, and Hikari in Yamaguchi; and Ohtake in Hiroshima. About one and a half hours after the 2000 Tottori-ken Seibu Earthquake, the Hofu Water Bureau dispatched a water tank truck, and five other trucks together with five engineers to Yonago at the request of the local government. Four other local governments, members of the agreement, provided 23 water tank trucks, and other types of trucks together with 38 engineers to engage in reconstruction efforts.

The Yonago Gas company provides 143,600 households in Yonago with city gas. Neither its gas production facilities, two spherical holders, nor a hydrate holder were damaged. Forty-three gas leaks occurred, most due to failure of the gas pipes in buildings. Damage to the main and branch gas pipes, however, was slight. The gas company could continue its supply because there were neither claim calls from users nor damage reports from firehouses.

Twelve instances of damage to sewage lines had been reported to the Civil Engineering Department in Tottori by October 10, 2000. These occurred in Yonago, Sakaiminato, Hino, Mizoguchi, Yodoe, and Hiezu. Damage mainly was due to the destruction of pipes and raised manholes.

For a while, telephone service in Mizoguchi was partially disrupted, and 134 lines were out of order in Tottori ${ }^{2}$. Telephone congestion occurred because of the flood of phone calls asking for safety confirmation. The Tottori Branch of NTT West therefore set up a message service at 2:00 p.m., and 3,200 messages were handled within 30 minutes. This was the largest number of messages taken so far in a disaster. 


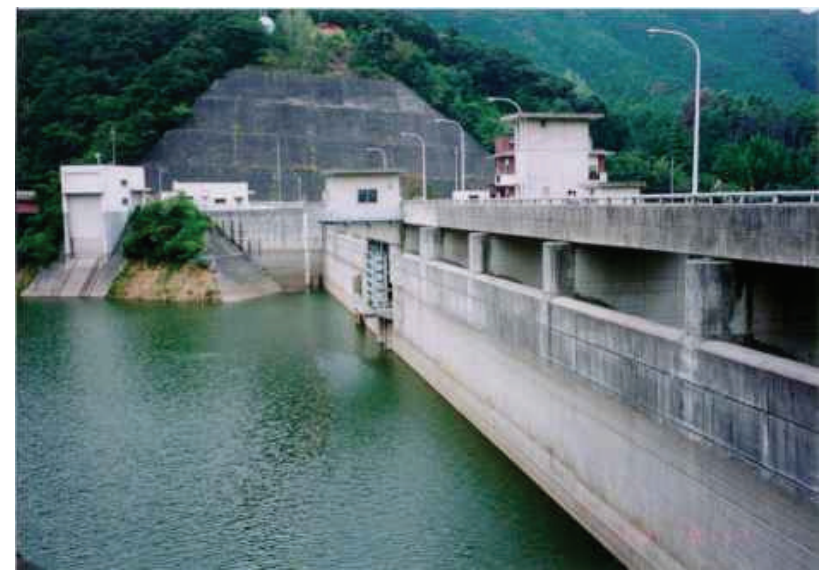

Photo 8 Gasho Dam (viewed from the right to left bank).

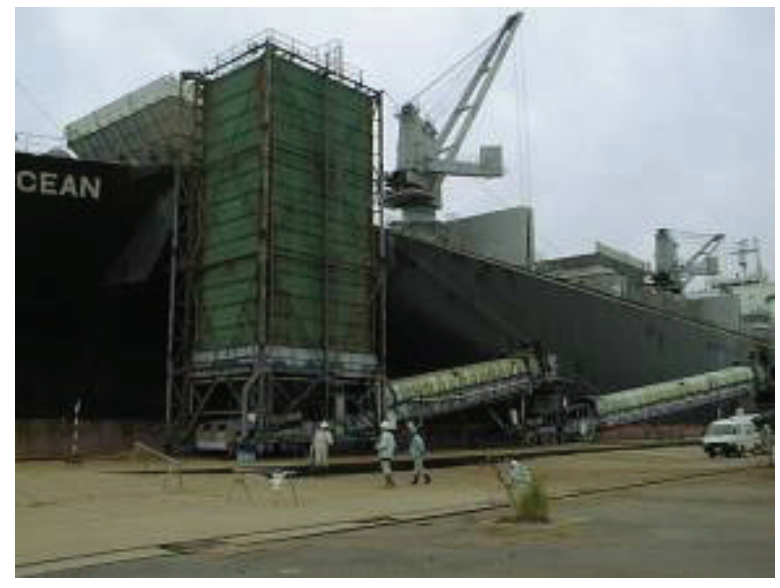

Photo 9 Damaged -13m quaywall at Showaminami.

(NS), 531.1gal (EW), 485.2gal (UD), and 2051.0gal (NS), 1406.2gal (EW), 884.2gal (UD), respectively.

\section{(2) Sugasawa Dam (lat. $35^{\circ} 12.1 ’ N$, long. $\left.133^{\circ} 19.1^{\prime} \mathrm{E}\right)$}

This is a multipurpose dam constructed by damming the Inga River. It is a gravity style, concrete dam $73.5 \mathrm{~m}$ high with a dam crest length of $210 \mathrm{~m}$, and a volume of $204,000 \mathrm{~m}^{3}$. Peak accelerations were recorded at the inspection gallery (EL326.0m, bed ground elevation EL317.0m) because the recorder installed on the rim was out of order before and during the earthquake. Observed peak accelerations at inspection gallery was 153gal (axial direction), 106gal (perpendicular direction), 66gal (UD).

\section{HARBOR FACILITIES}

Sakaikou, one of the most important harbors in Japan, was damaged. It has 6 mooring facilities, at which the front water depth is more than $7.5 \mathrm{~m}$. Five of these are located in the outer harbor, the other one in the inner harbor. As to their structural types, the outer harbor Showaminami quaywalls No.1-3 are of the gravity type, outer harbor piers No. 1 and 2 of the open type, and the inner harbor Ejima quaywall of the steel sheet-pile type.

The three gravity type quaywalls in the outer Showaminami area, have front sea depths from the west of $-7.5,-10$, and $-13 \mathrm{~m}$, and consist of replacement sand, rubble-mounds, and caissons, except for part of the $-7.5 \mathrm{~m}$ quaywall. The westernmost $-7.5 \mathrm{~m}$ quaywall was the only one reinforced for earthquakes. Its design seismic coefficient was 0.23 , larger than the values for the other mooring facilities (0.1 to 0.15 ). The backfill of the $-10 \mathrm{~m}$ quaywall had been improved by rod compaction. 


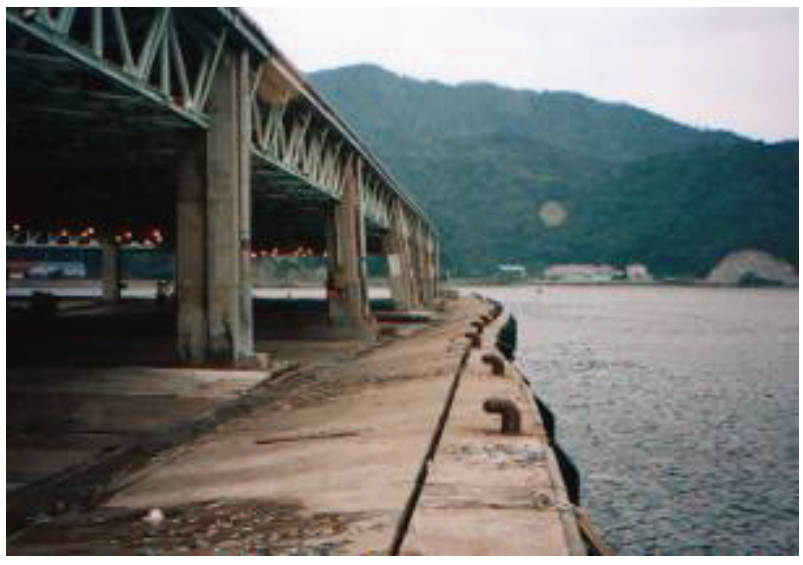

Photo 10 Damaged fishery wharf at Showakita.

Most of the backfill behind the caisson subsided, and vertical offset was generated between the backfill and caisson. The largest offset took place at the easternmost $-13 \mathrm{~m}$ quaywall, a $50 \mathrm{~cm}$ dislocation occurring between the apron and yards (Photo 9). Behind the quaywalls, traces of boiled-up sand produced by liquefaction were present around the columns. The relative displacements from the normal direction of all 3 quaywalls were small, therefore the bulging of the quaywall faces did not affect the moorings. Investigation confirmed that cargoes could still be handled because liquefaction under the paved backfill was not pronounced, the chip unloader worked well, and the front depth of the quaywall was sufficient. The outer harbor No.1 and 2 piers of the open type had little displacement in the normal direction, but there was an opening crack of about $7 \mathrm{~cm}$ behind the sheet piles. The Ejima steel sheet pile quaywall $(-9.0 \mathrm{~m})$ showed no outstanding damage, only a few cracks.

Those facilities with front sea depths below $-7.5 \mathrm{~m}$ in the outer harbor, in the Showakita and Tonoe areas, had no damage.

Unlike the major harbor facilities, the $-6.0 \mathrm{~m}$ quaywall of the Showakita fishery wharf, the so-called 'Kani Pier', was severely damaged (Photo 10). Liquefaction occurred, and the quay shed subsided a maximum of $0.6 \mathrm{~m}$ around its columns. Moreover, the face of the quaywall curved a maximum of $1.3 \mathrm{~m}$. The Takenouchi area, land reclaimed by dredge pumps, suffered wide liquefaction. Channel width in the reclaimed ground decreased by $2 \mathrm{~m}$, and the riverbed heaved a maximum of $1 \mathrm{~m}$. At the marina in the south of the area, three piers for yacht moorings embedded in the seabed collapsed. In general, where liquefaction occurred facilities were damaged.

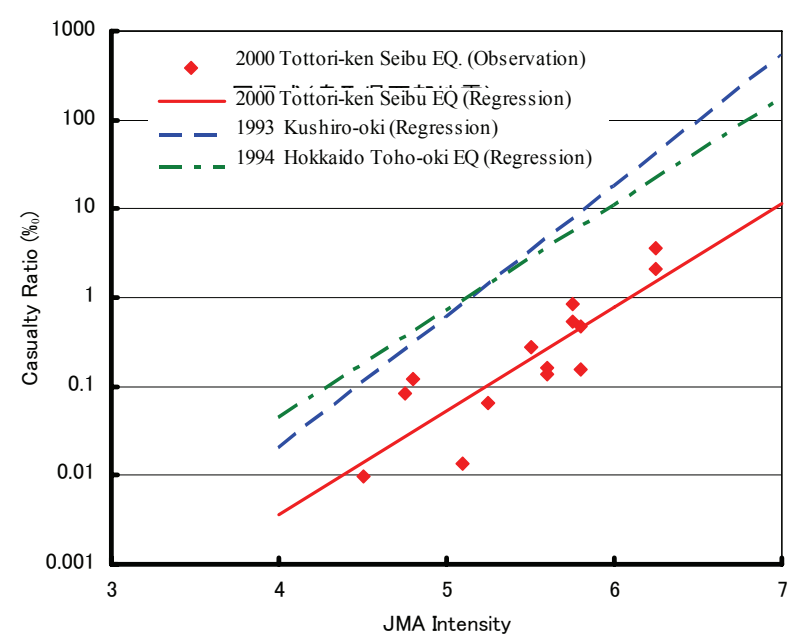

Fig. 7 Relationship between the JMA seismic intensity and casualty ratio.

\section{DISASTER RESPONSES}

\section{(1) Casualties}

The Fire Defense Agency of the Ministry of Home Affairs reported at 20:00 October 18 that no one had died, but the number of those injured totalled 131; 97 in Tottori, 10 in Shimane, 18 in Okayama, 3 in Hiroshima, 2 in Kagawa, and 1 in Hyogo. The causes were

\section{a) House collapse}

Of the houses damaged, few completely collapsed. One person was buried at a construction site but was rescued unharmed. Agarimichi Church in Sakaiminato and a shrine office in Hino completely collapsed. Fortunately, no one was injured because no meetings were being held at that time.

\section{b) Landslides, rock falls, and slope failures}

One car was wrecked by falling rocks, but the driver was rescued and had only slight injuries. One person buried under soil at an erosion control work site was rescued unharmed.

\section{c) Collapse of concrete blocks and gravestones}

Many concrete block walls collapsed and many gravestones toppled, but there were no human casualties. In the 1978 Miyagi-ken Oki earthquake, 28 people died due to the failure of concrete blocks and gateposts.

d) Overturning of furniture and household goods

Most injuries to people in this earthquake were due to the overturn of furniture and household goods.

\section{(2) Seismic intensity and the casualty ratio}

The casualty to seismic intensity ratio for this earthquake was lower than that for such past earthquakes as the 1993 Kushiro Oki Earthquake and the 
1994 Hokkaido Toho Oki Earthquake (Fig.7). The reasons for this need to be considered in terms of the earthquake-resistance performance of the timber frame houses in the Tottori area. Some reasons for the low number of casualties are that the earthquake took place on October 6 when heaters were not yet in use; it occurred at 13:30 when most people had finished lunch and no longer were using stoves; it happened in daylight, and people could recognize the circumstances and act cautiously; and as it was during school time, teachers could give directions to the students, most of whom stayed in their schools.

\section{(3) Persons injured}

Most of those injured had broken bones caused by falls. Aged women accounted for most of those injured. This is because $25-30 \%$ of the population is older than 65 in Hino, Kouhu, Mizoguchi, Saihaku, and Aimi (Basic Residents' Register, March 31, 1999).

\section{(4) Emergency responses}

\section{a) Fire department response}

The administrative group of local governments in southern Tottori is comprised of 14 municipalities, the core of which is Yonago and Sakaiminato cities (total population: 250,791, households: 87,048 as of April 1, 1999). It has 4 firehouses with 6 branches and a total of 25 fire trucks, 14 ambulances, and 287 officers.

Of the emergency responses taken, checks were made of damaged roads that were obstacles to fire fighting and emergency measures. These roads became accessible to emergency vehicles on October 7. Damage was done to roads at 405 sites, and more than 136 mudslides and 42 gas leaks occurred. Five fire call-outs were all false reports. Because the water pipelines in Yonago were ruptured and pressure could not be restored, more than one fire truck was not able to obtain water from fire hydrants.

There were 118 emergency call-outs, 135 people being transported between October 6 and 9. Of these, 82 call-outs involved the transport of 103 people to the hospital. There were 9 rescue call-outs, in which 4 people were helped. Organizations involved in disaster emergency responses; local governments, fire departments, electric power companies, telecommunication enterprises, the mass media, and hospitals, were all in working order and took immediate, smooth countermeasures to reduce possible disasters and accidents.

In support of existing efforts, 3 helicopters and a rescue team arrived on October 6, and another helicopter and 4 rescue teams on October 7.

\section{b)Damage to hospitals}

Hospitals depend on water, electricity, and gas utilities. If their supplies are disrupted, medical activities can not be carried out.

(i) Hino Hospitals: Due to the electricity outage and to structural failure at Hino Hospital, 13 patients had to be transferred to another hospital and 63 people evacuated to the gym in Neu Town. The Hino Town government reported that a new hospital was under the construction in the Noda area and was expected to be completed in November 2000.

(ii) Saihaku Hospital: Due to leakage from its water tank, patients were released or transferred elsewhere. (iii) Sakaiminato Saiseikai Hospital: Due to damage its structure and medical equipment, some patients were transferred elsewhere.

Because damage in Yonago was not severe, hospitals located in that city, including Tottori University Hospital, functioned properly and had no trouble in accepting patients, but there was some trouble with water pipes. The fire department could concentrate on using its crews for rescue and transfer work because there were no fires in the city.

\section{(5) Disaster information communication system}

Hino: There is a disaster prevention administrative radio and broadcast facility, and each household has a receiver.

Sakaiminato: A city officer assembly system had been introduced in 1995. Seismic intensity information is transmitted to the city office by the Meteorological Agency via the 'Himawari' satellites. Officers are assembled by means of pocket beepers. Disaster information is broadcast by administrative radio through 62 street speakers.

Yonago: Disaster prevention administrative radio had been introduced, and street speakers installed at 237 places by 1997 . During the 2000 earthquake, announcements were made about being cautious of fire and the use of gas.

Mizoguchi: All households have receivers for wire broadcasts. Disaster information also was communicated by the town's CATV.

\section{(6) Post-earthquake responses and victim support}

The Tottori Southern Fire Bureau reported 57 shelters had been set up and there were 906 evacuees as of 21:00 October 9. Evacuation instructions had been issued in Hino and Mizoguchi, and self-evacuations made in the other 2 cities and 5 towns. The disaster area was located where many aged people lived and that influenced such activities as safety confirmation, emergency rescue, clean-up, and recovery. Volunteers also worked in the area, and such organizations as the social welfare council 
supported their activities.

\section{(7) Future issues}

Fortunately, no one died in this 2000 earthquake, and the casualty to seismic intensity ratio was much lower than in past earthquakes. What would happen if an earthquake occurred during the night, or in winter, or if the magnitude were large needs to be considered. Such scenarios are of highly possible. To improve measures against disasters, it is important to consider the kind of damage that occurs, what actions should be taken, and what information needs to be communicated. This earthquake was caused by an active fault, which had not earlier been identified. It generated large seismic ground motions and the disaster. There must be many unknown buried faults yet to be recognized as being potentially active.

\section{CONCLUDING REMARKS}

Findings on the 2000 Tottori-ken Seibu Earthquake by the reconnaissance team:

(1) Large amplitude accelerations were recorded at Kik-net Hino (NS 927gal) and K-net Kohu (NS 726gal). Peak accelerations larger than $1 \mathrm{G}$ were observed at some local governments, but no wave data was recorded.

(2) Accelerations for which observation points were close together differed markedly, as in the records at Sakaiminato (the meteorological observatory, city hall, and harbor office) and Hino (the KiK-net site and town hall). Seismic intensities accurately indicated the magnitudes of ground motion at those observation points. It must be noted, however, that those accelerations could be used to estimate the damage done to various structures in the area because they represent pinpoint information only.

(3) Liquefaction occurred along the Nakaumi littoral in Sakaiminato, Yonago, Yasuki, and Matsue cities, all located within $30 \mathrm{~km}$ of the epicenter. Marked damage was done to market gardens on Hikona reclaimed farm land, to houses in the Hikona and Nishikiumi housing estates, and to buried pipes in the Takenouchi industrial park.

(4) Large slope failures were few for this earthquake's large seismic ground motion. Because the soil in the western Daisen area is a consolidated ash flow produced by the eruption of Mt. Daisen about 26,000 years ago, its adherence property prevented slope failure. Some ground, however, was softened by the earthquake, and was at risk of failure.
(5) As for water supplies, the mutual aid system formed by the local governments of Yonago in Tottori; Hofu, Iwakuni, Ube, and Hikari in Yamaguchi; and Otake in Hiroshima after the 1995 Hyogo-ken Nanbu earthquake, worked efficiently in the wake of the 2000 earthquake.

(6) At Gasho Dam, located in the aftershock area, seismometers had been installed in the inspection gallery (EL87.0m, bed ground elevation: EL78.0m) and the elevator shaft (EL124.4m). The peak accelerations recorded in the elevator shaft were some of the largest so far recorded for dams (NS 2051.0gal, EW 1406.2gal, UD 884.2gal). Nothing abnormal, however, was reported regarding the safety and function of that dam.

(7) Fortunately, no one died in this earthquake. Moreover, the casualty to seismic intensity ratio was much lower than in past Japanese earthquakes. What would have happened if this earthquake had occurred at night, or in winter, or if its magnitude had been larger must, however, be considered. Such scenarios are highly possible.

ACKNOWLEDGMENT: We had the collaboration of Yoshikazu Yamaguchi (Public Works Research Institute: dams), Osamu Matsuo (Public Works Research Institute: roads and bridges), Masanori Oomaki (National Research Institute of Fisheries Engineering: harbors), Atsushi Nozu (Port and Airport Research Institute: harbors), and Koichi Takimoto (Yamaguchi University: disaster responses). We express our sincere appreciation to all of these collaborators.

\section{APPENDIX}

The Japan Society of Civil Engineers (JSCE) dispatched a reconnaissance team of eight members between October 8 and 10 (some members from 20 to 22 Oct.), 2000: Junji Kiyono (Team leader: Kyoto University: seismic ground motion), Ryoji Isoyama (Japan Engineering Consultants Co., Ltd.: liquefaction), Yoichi Taji (Institute of Technology, Shimizu Corporation: liquefaction), Susumu Nakamura (College of Engineering, Nihon University: seismic ground motion), Takao Hashimoto (Chiyoda Engineering Consultants Co., Ltd.: landslides), Masanori Hamada (Waseda University: liquefaction), Tadafumi Fujiwara (Taisei Cooperation: ground and soil disasters) and Masataka Miyajima (Kanazawa University: lifelines). This report was co-written with 
Kazuo Konagai (Institute of Industrial Science, the University of Tokyo), Tomofumi Nozaki (Ministry of Land, Infrastructure and Transport), Koji Ichii (Hiroshima University; Port and Airport Research Institute as of 2000), and Hitomi Murakami (Yamaguchi University), who investigated during the same period for their own organizations.

\section{REFERENCES}

1) Japan Meteorological Agency: On the 2000 Tottori-ken Seibu earthquake, Documents for press at 17:50 on October 6, 2000 (in Japanese).

2) Fire Defense Agency: The 2000 Tottori-ken Seibu earthquake (63rd report), http://www.fdma.go.jp/, August 2, 2001 (in Japanese).

3) Kikuchi, M. and Yamanaka, Y.: EIC seismology note No.93, October 6, 2000, Earthquake Research Institute of the University of Tokyo, http://kea.eri.u-tokyo.ac.jp/EIC /EIC_News/ 001006. html (in Japanese).

4) Geographical Survey Institute, the Ministry of Construction: Basic concept of the fault model, October 7, 2000, http://www.gsi-mc.go.jp/WNEW/PRESS-RELEASE/2000 /1007-2.htm (in Japanese).

5) Earthquake Prediction Research Center, Disaster Prevention Research Institute, Kyoto University: Dense observations of aftershocks (Joint earthquake observation by universities nation-wide), http://www2.rcep.dpri. kyoto-u.ac. jp/ sato/tottori/index _j.html (in Japanese).

6) Sekiguchi, H. and Iwata, T.: Estimation of the fault rupture process by use of seismograms of the K-net, KiK-net, Re- search Section for Earthquake Disasters, Dis. Prev. Res. Inst., Kyoto University, http://sms.dpri.kyoto-u.ac.jp/iwata /ttr.source.html (in Japanese).

7) Japan Meteorological Agency: On aftershock activities of the 2000 Tottori-ken Seibu earthquake, Documents for the press at 18:00 on October 16, 2000 (in Japanese).

8) National Research Institute for Disaster Prevention: Kyoshin Net (K-NET), http://www.k-net.ostec.or.jp/k-net_ docs/kyoshin.html (in Japanese).

9) National Research Institute for Disaster Prevention: KiK-Net, http://www.kik.bosai.go.jp/kik (in Japanese).

10) Port and Airport Research Institute, the Ministry of Land, Infrastructure and Transport: Investigation report of the 2000 Tottori-ken Seibu earthquake (provisional edition), http://www.phri.go.jp/jishin/index.html (in Japanese).

11) Editing Committee for the Chugoku Region Engineering Geological Map: Civil Engineering Geological Map of the Chugoku Region, 1984 (in Japanese).

12) Planning Bureau, the Ministry of Construction: Soil of the Nakaumi littoral, Urban Ground Survey Report, No.15, pp.142, 1967 (in Japanese).

13) Yamaguchi, K.: Series of Historical Maps of Japan, Chugoku, Asakura Shoten, 1975 (in Japanese).

14) Wakamatsu, K.: Map of Historic[sic] Liquefaction Sites in Japan, Tokai University Press, 1991 (in Japanese with English title).

(Received April 18, 2006) 